\title{
Obituary: Remembering Emeritus Professor Lester Mitscher (20 August 1931-8 May 2015)
}

\author{
The Journal of Antibiotics (2015) 68, 601-602. doi:10.1038/ja.2015.75
}

$I^{\prime}$ $t$ is with deep sorrow and a sense of great loss that all of his colleagues experience the passing of Lester (Les) Mitscher after a brief bout with cancer. Les was born in Detroit to Czechoslovak immigrants, Mary and Lester Mitscher, who must have instilled in him a great lust for education. He was valedictorian of his high school and went on to earn a BS in Pharmacy and a PhD in Organic Chemistry at Wayne State University as one of Carl Djerassi's first graduate students. Promptly on receiving his Bachelors degree he married his high-school sweetheart Betty McRoberts, and they had three children, Katrina, Kurt and Mark, the beginning of an extended family to which he was very devoted. Les's $\mathrm{PhD}$ work was on diterpenes from coffee and optical rotatory dispersion, and he followed this by joining Lederle Laboratories as a natural product research scientist, where he became the leader of the antibiotic discovery group. In that capacity he became an expert on the chemistry and biosynthesis of tetracyclines. In 1967 Les returned to academia as an Associate Professor of Natural Product Chemistry in the School of Pharmacy at Ohio State University. While here, Dr Tom Perun of Abbott Laboratories invited him to consult on the structure determination of a novel tetracycline, chelocardin (cetotetrine), which had been discovered by Abbott Pharmaceutical Research scientists. Les's consulting skills were phenomenal. Not only did he have an extremely broad knowledge of all aspects of drug discovery, he had an ability to suggest a new approach in a way that the listener felt that he (the listener) was the one who actually thought of it. The combination of his breadth of knowledge and this unique skill kept Les in high demand from the scientific staff and he went on to be Abbott's longest serving continual scientific consultant (37 years). For about 12 years I had the responsibility of drawing up the itinerary for Les's visits to Abbott. His schedule would always be filled 2 weeks before he arrived. Les was a man of high ethical standards, and despite the fact that he had simultaneous consulting contracts with several pharmaceutical and biotechnology companies there was never the slightest indication that he divulged confidential information from one to another. (Yet another, almost unique skill!)

In 1975 he was invited to become distinguished Professor and Chairman of the Department of Medicinal Chemistry at the University of Kansas, a department that had already achieved world recognition under the previous chairman, Edward Smissman. He stepped down as department Chairman in 1992, to devote more time to his research group, which he ran as Distinguished Professor and then as an Emeritus Professor until 2011. Les's research group was incredibly productive, and although natural products and antibiotics in particular were probably his greatest scientific interest, he published broadly in

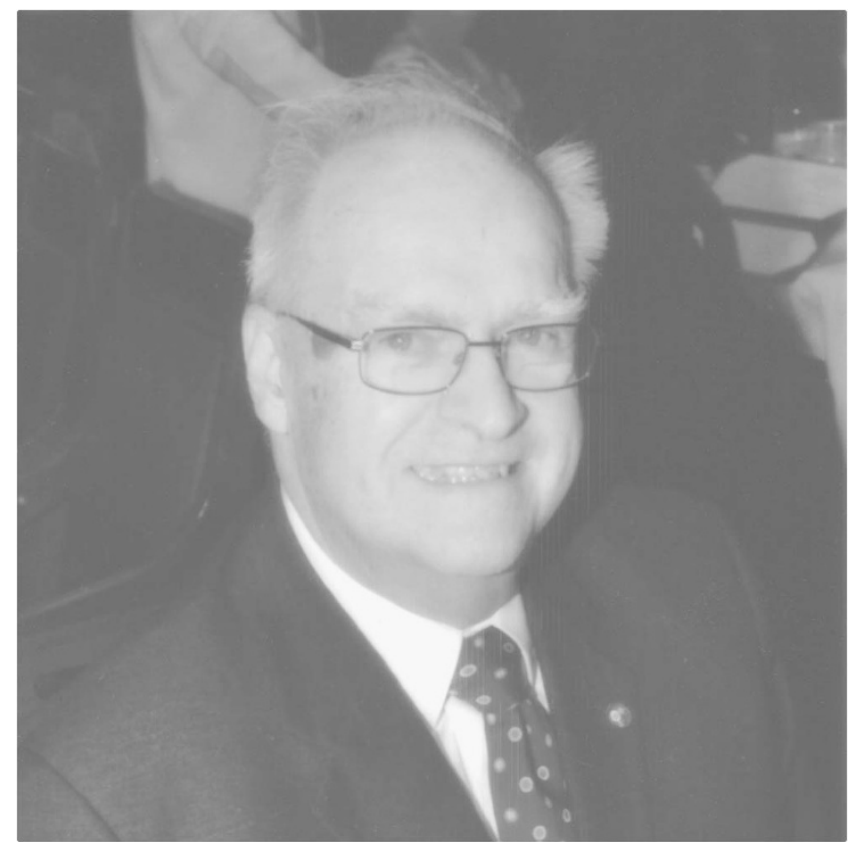

drug discovery. He realized early after the advent of combinatorial chemistry that the role of this technology was in lead optimization rather than in lead discovery and he used it accordingly (an insight which escaped many in the management levels of the pharmaceutical industry). Les was on the Editorial Board of several scientific journals including $J A$, where he served from 1974 until he achieved emeritus status in 2002. A previous Managing Editor of the Journal, Dr Morimasa Yagisawa, undertook postdoctoral studies in Les's lab as part of his early training.

Les was the recipient of many prestigious awards, including the highest award given by the American Society of Pharmacognosy, of which he was president in 1992-1993 (the Norman R Farnsworth Research Achievement Award), The Bristol-Myers Squibb Smissman Award for Medicinal Chemistry given by the American Chemical Society, the Ernest $\mathrm{H}$ Volweiler Award given by the American Association of Pharmacy Colleges and the Higuchi-Simmons Award in Biomedical Sciences. He was a Fellow of the American Association for the Advancement of Science and a Fellow of the American Society 
of Pharmacognosy and a Distinguished Fellow of the International Union of Pure and Applied Chemistry.

Les was sought after as an expert witness in many high-level patent litigations covering the inventions of marketed pharmaceuticals or methods to discover drug leads.

As well as his great knowledge and love of science, Les had a deep knowledge of both history and geography, and he and Betty loved to travel. The last communication I had with him were a few intermittent e-mails last year when he and Betty were on a cruise visiting the northernmost settlement, Ny-Alesund, on the island of Svalbard, Norway, then Murmansk and on to St Petersburg. These e-mails were both educational and a joy to read. Les and Betty had done most of the more normal tours, this year, while the first symptoms of the as-yet-undiagnosed rapidly spreading cancer were becoming apparent, the two of them were touring Australia and New Zealand.

The world has lost a great educator, a great scientist, and his colleagues have lost a solid sounding board and a generous contributor. His fellow members of the Editorial Board and the staff of the Journal extend their heartfelt sympathy to Betty and all of Les's family.

James (Jim) McAlpine Department of Medicinal Chemistry and Pharmacognosy, University of IL at Chicago, College of Pharmacy, Chicago, IL, USA E-mail: mcalpine@uic.edu 